\title{
Wstęp
}

\section{Odkrywanie zmysłu udziału}

Ryszard Nycz

TEKSTY DRUGIE 2018, NR 1, S. 7-15

DOI: 10.18318/td.2018.1.1

Możesz mnie poznać, nie zaznasz mnie nigdy.

$[\cdots$

- Nie wejdziesz - mówi kamień. -

Brak ci zmysłu udziału.

Nawet wzrok wyostrzony aż do wszechwidzenia

Nie przyda ci się na nic bez zmysłu udziału.

Nie wejdziesz, masz zaledwie zamysł tego zmysłu,

ledwie jego zawiązek, wyobraźnię.

Wisława Szymborska Rozmowa z kamieniem ${ }^{1}$

\section{1.}

Zapisałem w tytule "zmysł udziału” bez cudzysłowu, bo mam poczucie, że to określenie Szymborskiej ma charakter ważnego poetyckiego wynalazku, który tyleż uświadamia istotny niedostatek charakteru nowoczesnego ludzkiego poznania, co sygnalizuje możliwą jego reorientację, antycypując kierunek poszukiwań, którym oddają się współcześnie nie tylko literatura i sztuka, lecz także nauki humanistyczne. Ma więc

1 W. Szymborska Rozmowa z kamieniem, w tejże Zmysł udziału. Wybór wierszy, Wydawnictwo Literackie, Kraków 2006, s. 8-9.
Ryszard Nycz - prof.

dr hab., kierownik

Katedry Antropologii

Literatury i Badań

Kulturowych U),

pracownik IBL PAN.

Redaktor naczelny

"Tekstów Drugich".

Członek rzeczywi-

sty PAN i członek

korespondent PAU,

KNoL PAN i KNoK

PAN. Przewodniczący

Komitetu Redakcyj-

nego serii „Nowa Humanistyka." Ostatnio opublikował: Poetyka doświadczenia. Teoria-nowoczesność literatura (2012) i Kultura jako czasownik. Sondowanie nowej humanistyki (2017). Kontakt: ryszard. nycz@uj.edu.pl 
wszelkie dane, by wejść do potocznego obiegu jako poręczna formuła tych poszukiwań. Plastyczna i wyrazista a prosta zarazem poetycka alegoria natury ludzkiego poznania, którą nakreśliła Szymborska w Rozmowie z kamieniem, uczyniła ten utwór jednym z najbardziej rozpoznawalnych i cenionych jej wierszy. A równocześnie nadała 'odgrywanemu' tam dialogowi człowieka z naturą charakter wzorcowego przykładu, w który wpisana została większość z filozoficznych założeń, na których oparty został ten model poznania.

Ujmuje on bowiem ludzkie poznanie w dualistycznych kategoriach, w których nowoczesność zwykła porządkować relacje podmiotu ze światem: kultury i natury, ducha i ciała, świadomości i materialności. Egzystencja człowieka ma w tej perspektywie charakter przygodny (kontyngentny), czasowy i przemijający; kamienny świat natury jest figurą tego, co pozahistoryczne, stałe i niezmienne. Człowiek poznaje (przedstawia sobie, reprezentuje) świat, stając naprzeciw, na zewnątrz niego. Ten zewnętrzny a także statyczny ogląd ma charakter intelektualny (bezcielesny), co ma umożliwiać neutralność (niezaangażowanie) oraz obiektywność (bezosobowość, niesubiektywność) rezultatów poznania. Ta szkolna charakterystyka (czemu zresztą ten wiersz służył na lekcjach paru już uczniowskich pokoleń) eksponuje te cechy natury ludzkiego poznania, które wynikają właśnie z konieczności - i zarazem przywileju zajmowania zewnętrznego stanowiska obserwacyjnego; autonomii, a to znaczy też: izolacji wobec porządku naturalnego (nieprzynależności do niego i zarazem niezdolności do udziału w nim).

Strategia poetycka Szymborskiej polega oczywiście na odwróceniu tych hierarchii i wartościowań; na odsłonięciu w tryumfującej władzy humanistycznego antropocentryzmu - narcystycznej arogancji, w przywileju - rodzaju wykluczenia, w specyficznie ludzkiej władzy intelektualnego poznania - dysfunkcji, niedoboru, braku. Imperialna władza poznania jako pojęcia, zawładnięcia rzeczą ma charakter powierzchowny, instrumentalnego podporządkowania zewnętrznym celom, nie sięga wnętrza - którego można tylko „zaznać", a więc doznać, doświadczyć na drodze aktywnie pasywnej partycypacji w wewnętrznym porządku rzeczy. Zobaczyć zaś w zdolności do kontemplatywnego (oderwanego od życia) oglądu nie tyle unikatowy boski dar, co'przyrodzony' brak czy dysfunkcję - to ująć człowieka od strony wstydliwych kulis jego empirycznego istnienia, to dostrzec w nim 'istotę wybrakowaną', o rodowodzie ciągnącym się od Platona (i jego Protagorasa) przynajmniej po Geertza; istotę, której źródłem, niewyczerpywalnym rezerwuarem aktywności jest ów niedostatek i niedobór, którego nigdy całkowicie nie daje się uzupełnić czy nasycić. Wyobraźnia, zwłaszcza poetycka, może pełnić funkcję 'zawiązka' tej zdolności, ponieważ niejeden raz zapuszczała się do wnętrza rzeczy (poznawania innego), sondując fantazmatycznie jej możliwe krajobrazy... 
2.

Przywołuję ten odległy (także w czasie - sprzed ponad półwiecza) literacki przykład, bo - mnie przynajmniej - pozwala lepiej zrozumieć zamysł antropologicznej awangardy, zmierzającej do zbudowania etnografii przedtekstowej. Jej zarys, a także genealogię i konteksty przedstawił już parę lat temu Tomasz Rakowski w swojej klasycznej książce Łowcy, zbieracze, praktycy niemocy. Etnografia człowieka zdegradowanego², a jej współczesne warianty zawierają główne artykuły polskich i zagranicznych autorów w tym numerze. Niemniej jednak nie jest to dalej - w każdym razie dla takiego ignoranta jak ja - w pełni czytelna w swoich założeniach i celach orientacja badawcza, choć bez wątpienia wciąga czytelnika frapującym kierunkiem prowadzonych poszukiwań.

Pierwszą trudność może sprawić oksymoronicznie brzmiąca nazwa. Badaczom literatury z pewną pomocą przychodzą współczesne praktyki nowych edytorów, nazywających edytorstwem przedtekstowym zajmowanie się rękopisami... A to dlatego, że w odróżnieniu od zamkniętej, ustalonej, ostatecznej wersji tekstu autorskiego mamy tu do czynienia z zapisanym procesem poszukiwania, wielością wersji, wariantowością koncepcji całości etc. Trochę podobnie z etnografami: zdaniem Tomasza Rakowskiego terenowe zapiski mają właśnie charakter "przedtekstowy”, ponieważ nie zawierają opisu pojęciowo-symbolicznego systemu przekonań i wyobrażeń poznawanych jednostek i wspólnot oraz nie utrwalają jego reprezentacji w dyskursywnym porządku'ostatecznej', zamkniętej postaci tekstu etnograficznego, lecz stanowią rodzaj symptomów czy indeksalnych wskaźników, odsyłających do niezwerbalizowanej jeszcze i nieujętej w pojęcia części doświadczenia etnograficznego. Generalnie biorąc, etnografowie tej orientacji uważają, że konwencjonalny sposób zapisu reifikuje, substancjalizuje i, ogólnie biorąc, zniekształca przedmiot - który nie jest właśnie tradycyjnie pojętym przedmiotem, uprzednio i niezależnie od poznającego istniejącym a reprezentowanym przez logiczno-semiotyczną strukturę dyskursu, lecz rejestracją stabilizującej się konstelacji związków organizmu ze środowiskiem (tj. wzajemnych relacji wszystkich aktorów - ludzi, zwierząt, roślin, rzeczy, narzędzi - z otoczeniem).

Inaczej mówiąc, chodzi, jak to krótko określa Kirsten Hastrup, o „praktykowanie umiejętności abdukcji pośród świata o nieograniczonych afordancjach"3. Żeby jednak to zdanie stało się jaśniejsze, trzeba by poprzedzić je paroma założeniami i poczynić kilka wyjaśnień. Po pierwsze, wygląda na to, że zadaniem współczesnej etnografii nie jest już tylko opis ludzkiego społeczeństwa (czy wspólnoty). Trzeba porzucić rozpatrywanie

2 T. Rakowski Łowcy, zbieracze, praktycy niemocy. Etnografia człowieka zdegradowanego, słowo/obraz terytoria, Gdańsk 2009. O etnografii przedtekstowej zob s. 9-45.

3 K. Hastrup Świadomosć mięśniowa. Wytwarzanie wiedzy w Arktyce, w tym numerze. Do tego prototypowego ujęcia będę się tu odwoływać jeszcze parokrotnie. 
relacji człowieka do świata w dualistycznych kategoriach nowoczesnego poznania. Po prostu dlatego, że znaczenie tego, co robi człowiek, nie daje się już uchwycić w oderwaniu od jego relacji ze środowiskiem, które również przestaje być traktowane jako bierne tło, a staje się aktywnym, sprawczym partnerem, współtworzącym znaczenie i obraz człowieka i świata (a raczej człowieka w świecie). Antropologiczno-etnograficzne poznanie obejmuje więc, co ważne, nie tylko ludzi, lecz i środowisko, w którym funkcjonują. Od teorii afordancji, wpisanej w ekologiczną psychologię percepcji Jamesa Gibsona, po Latourowską koncepcję sieci tworzonej przez sprawczo działających aktorów (ludzkich i nieludzkich) - rozpościera się ten nowy obszar antropologicznego doświadczenia, w którym sytuowane są badania etnografów przedtekstowych.

Jeśli tak, to, po drugie, uchwycenie i dostęp do tego świata z tradycyjnej, zewnętrznej perspektywy neutralnego naukowo oglądu nie może się powieść. Zewnętrzną obserwację zastąpić musi partycypacja, poznanie uczestniczące. Możliwość transcendującego nasze cielesne osadzenie spojrzenia (,wzrok wyostrzony aż do wszechwidzenia"), zajęcia zewnętrznego stanowiska obserwacyjnego na spektakl ludzkiego życia, to utopijne założenie nowoczesnego poznania, które prowadzi do zniekształcenia i charakteru poznania, i jego wyników. Wedle bowiem znanych orzeczeń fundatorów tej orientacji: nie żyjemy na świecie, lecz w świecie (Ingold), a świat ten poznać możemy tylko wtedy, gdy poczujemy się jego częścią (Hastrup). W procesie tego poznawania od wewnątrz zmysł wzroku traci swoją pozycję uprzywilejowanego narzędzia poznania, wypierany przez "dotykowe widzenie", rozpoznające kontury rzeczy i kontaktujące się ze światem niczym laska w ręce niewidomego (Rakowski).

W tym kontekście powraca, po okresie krytyki, formuła „obserwacji uczestniczącej”, która od czasów Malinowskiego określała strategię antropologiczno-etnograficznych badań. Może być ona chyba jednak nieco myląca. W wersji klasycznej oznaczała ona zdolność antropologa do wejścia w krąg doświadczeń, znaczeń i symboli badanej wspólnoty, a następnie przełożenia ich na "uniwersalny" język naukowej antropologii, który z czasem ujawniać zaczął wyraźne rysy zachodniego, eurocentrycznego stanowiska, które niejako odbiera głos innemu, by wypowiadać się w jego imieniu... Tymczasem w tym przypadku chodzi, jak się wydaje, o odwrócenie kierunku „translacji” i dostosowanie języka opisu w największym możliwym stopniu do specyfiki opisywanego świata. Inaczej mówiąc, chodzi właśnie o ocalenie tego, co przepadało w tamtym tłumaczeniu. Wygląda więc moim zdaniem, że formuła "poznania uczestniczącego" lepiej zdaje sprawę z tej praktyki.

Co ważne, owo poznanie uczestniczące nie zakłada tu bynajmniej możliwości osiągnięcia mitycznego dostępu do poznawania innego od wewnątrz, do empatycznej identyfikacji, przełamania komunikacyjnych barier. Doświadczeniowy udział pozwolić ma badaczowi na uchwycenie „kombinujących się wokół mnie kombinacji” między 
ludźmi, rzeczami oraz żywym i nieożywionym otoczeniem (by posłużyć się frazą Gombrowiczowskiego narratora Kosmosu), albo inaczej mówiąc (za Hastrup, w przywoływanym tu już artykule), ma mu pozwolić na "skonfigurowanie świata - jednak nie poprzez naśladowanie świata myśliwych (czy kogokolwiek innego), lecz dzięki tropieniu istotnych związków między znaczącymi aktorami, ludzkimi i nieludzkimi, w miarę, jak pojawiają się one w toku realnego życia". Przywrócona dzięki Alfredowi Gellowi ${ }^{4}$ współczesnej praktyce etnograficznej Peirce'owska metoda abdukcji pozwala powiązać indeksalne znaki w konstelacyjną sieć interferencyjnego wnioskowania, która wyposaża te sygnałowe znaki świadczące o istnieniu tego, co je wywołało, lecz pozbawione znaczenia - w pojęciowe znaczenie właśnie oraz dostarcza hipotetycznego wyjaśnienia owego "sprawstwa" badanego zdarzenia.

Poznanie to urzeczywistnia się w działaniu, a spełnia, zapisuje, w sprawnościach i dyspozycjach ciała. Niczym Heideggerowskie rozumienie się na czymś, rozumienie czynne, które jest zdolnością do wykonania tego czegoś, etnograficzne wytwarzanie wiedzy w terenie realizuje się w postaci umiejętności ("wiedzy jak”), pojmowanych jako "zdolności do działania i postrzegania". Wydaje się więc, że można by powiedzieć, że ta etnografia jest przedtekstowa dlatego przede wszystkim, że wytworzona czy uzyskana w toku działania i „,współzamieszkiwania” wiedza badacza jest najpierw wiedzą ucieleśnioną przez niego, jest jego „świadomością mięśniową”. Jak to ujmuje Tomasz Rakowski, ,"etnografia jest zapisem ucieleśnionego i intersubiektywnego doświadczenia obecnego naraz w przekształceniach badanego świata, i w owej «wewnętrznej drodze» badacza $[. . .]^{\prime \prime 5}$.

\section{3.}

Rozumienie znaczenia jako prymarnie ucieleśnionego mogłoby zachęcać do wsparcia argumentacji etnografii przedtekstowej odwołaniem do podobnie zorientowanych filozofii języka - czego jednak śladów praktycznie nie ma. Można nawet odnieść wrażenie, że badania te omijają (świadomie?) szerokim łukiem tę tradycję. Być może działa

4 Zob. A. Gell Art. and Agency: An Anthropological Theory, Oxford University Press, Oxford 1998. Por. w tej sprawie opracowanie A. Kawalec Osoba i Nexus. Alfreda Gella antropologiczna teoria sztuki, Wydawnictwo KUL, Lublin 2016. Aktywowanie tej semiotycznej metody i tradycji w etnografii przedtekstowej jest dodatkowo intrygujące w świetle uwagi U. Eco, którego zdaniem „ogólny mechanizm abdukcji można oddać jasno tylko jeśli założymy, że będziemy traktować światy jako teksty, a teksty jako światy". Zob. U. Eco Rogi, kopyta, buty: trzy typy abdukcji, w tegoż Czytanie świata, przeł. M. Woźniak, Znak, Kraków 1999, s.112.

5 T. Rakowski Etnografia przedtekstowa. Fenomenologiczne korzenie interpretacji antropologicznej (w tym numerze). 
tu dalej odium sławnego dictum Derridy („nie ma nic poza tekstem”), często acz błędnie interpretowanego jako odrzucenie możliwości istnienia/poznania przedtekstowej i przedjęzykowej rzeczywistości. A może raczej w grę wchodzi wola niewykraczania poza wewnątrz-dyscyplinowe konteksty tych poszukiwań... Jakkolwiek by było, sądzę, że ten kontekst filozoficznej antropologii języka nie tylko nie koliduje z przyjętym kierunkiem poszukiwań, ale może go wspierać a nawet legitymizować.

Wydaje się niewątpliwe, że orientacji tej patronować może z oddali autorytet Nietzschego, dostrzegającego, że skuteczna komunikacja, rozumienie innego, dokonuje się nie tyle dzięki sprawnemu zdekodowaniu pojęciowego przekazu, co raczej za sprawą naszej zdolności do aktywowania w pojęciu „odczuwanego znaczenia” osadzonego w residuum wspólnego doświadczenia ${ }^{6}$. Współcześnie zaś ten nurt myślenia reprezentuje językoznawstwo kognitywne, czy to w wersji doświadczeniowego realizmu Georgesa Lakoffa i Marka Johnsona, czy kognitywistycznego enaktywizmu Alva Noe, czy na rozmaite liczne inne sposoby. Być może za tradycję kluczową w tym nurcie powinna zostać jednak uznana przede wszystkim antropologiczna filozofia języka Eugena Gendlina, wypracowywana przez tego badacza od lat 60.

Paralele bowiem nasuwają się same. Tak jak etnografia obejmuje dziś swym opisem nie tylko ludzi, ale i świat, w którym działają, tak język - zdaniem Gendlina obejmuje nie tylko słowa, ale i sytuacje; nie jest wyłącznie werbalny . Sytuacje są ucieleśnionymi sytuacjami doświadczeniowymi, dzięki którym znaczenia są aktywowane. Oznacza to, że znaczenia rodzą się i wyłaniają z doświadczenia (nie z relacji wewnątrz-semiotycznych między znaczącym a znaczonym) i w tej fazie zachowują status „znaczenia odczuwanego", nie dającego się zawrzeć w pojęciu czy na niego przełożyć, co nie znaczy, z drugiej strony, że są one zupełnie „plazmatyczne” i nieokreślone. Całkiem przeciwnie; stawiają opór dowolnym próbom ich uchwycenia w słowach i pojęciach. Są czymś pośrednim, co nie jest ani zupełnie niezależne od słów, ani całkowicie w nich nie jest zawarte.

Gendlin analizuje w tym charakterze m.in. poetycki proces twórczy, żeby pokazać, że poeta, poszukując właściwego słowa czy frazy, a odrzucając warianty roboczo wypróbowywane, dowodzi tym samym, że owo znaczenie odczuwane ani nie jest

6 Zob np. F. Nietzsche Nachlass. Pisma z lat 1884-1885, przeł. G. Kowal, posłowie G. Colli, PWN, Warszawa 2011, 5375 .

7 Zob. E. Gendlin Let Your Body Interpret Yours Dreams, Wilmette 1986, s. 144. Zob. także podstawową monografię Gendlina Experiencing and the Creation of Meaning. A Philosophical Approach to the Subjective, Northwestern University Press, Evanston, IL 1997 [1 wyd. 1962] oraz tom zbiorowy poświęcony jego filozofii języka (z jego komentarzami) Language beyond Postmodernism, Saying and Thinking in Gendlin's Philosophy, ed. by D.M. Levin, Nortwestern University Press, Evanston, IL 1997. 
przedwerbalnie ukształtowane, ani nie dopasowuje się biernie do arbitralnie wybranego wyrażenia; jest na swój sposób precyzyjnie sprofilowane, ewoluując i krystalizując się stopniowo w procesie dochodzenia do właściwego pojęcia i wyrazu (przykładem podobnego rodzaju posłużył się wcześniej William James, analizując w sławnym fragmencie proces poszukiwania właściwego słowa, które mamy, jak to się powiada, „na końcu języka"). Przed podobnym wyzwaniem stają etnografowie w procesie wytwarzania wiedzy w terenie, kiedy dążą do znalezienia najlepszej artykulacji dla ucieleśnionej, odczuwanej, motorycznej wiedzy, którą posiedli w toku czynnego, uczestniczącego procesu poznania.

Z tego punktu widzenia znaczenie nie jest zjawiskiem wyłącznie językowym, a język nie jest wyłącznym nośnikiem znaczenia - może być ono ucieleśniane, odgrywane, afektywnie transmitowane, w rozmaitych formach społecznej interakcji symbolicznej czy ekspresji. Mark Johnson, analizując Gendlinowską filozofię języka ${ }^{8}$, nie rozstrzyga zdecydowanie, jaką należałoby pójść drogą; z perspektywy np. analitycznej filozofii języka siedlisko znaczenia jest pozajęzykowe, z punktu widzenia Gendlina czy tradycji pragmatycznej - należy do szeroko rozumianego języka. Można by powiedzieć, że jest kwestią wyboru, czy zawężając rozumienie języka do słowno-zdaniowej struktury, uznamy znaczenie ucieleśnione za zjawisko pozajęzykowe, czy też rozszerzając jego pojęcie na wszelkie formy symbolicznej interakcji, potraktujemy owo znaczenie ucieleśnione jako wewnętrzny komponent językowego działania. Świadomie czy bezwiednie podejmowane decyzje antropologów i etnografów tej orientacji określają jednak również ich stanowiska w tym sporze.

\section{4.}

Etnografowie przedtekstowi mają oczywiście świadomość, że nie przekraczają bariery ludzkiego poznania; pracują, wedle zręcznego określenia Kirsten Hastrup „na krawędzi natury". Aktywowany przez nich „zmysł udziału” pozwala im jednak obrysowywać niekiedy bardzo subtelnie, pomysłowo i odkrywczo - punkty styku społeczno-kulturowego i cielesno-materialnego, i przesuwać w ten sposób granice antropocentrycznego poznania aż do tej sfery doświadczanych sytuacji, gdzie zawiązuje się i rozwija znaczenie odczuwane. Jeśli przez zmysły rozumiemy zazwyczaj naszą zdolność do reagowania na zewnętrzne bodźce płynące z otoczenia (wzrokowe, słuchowe, węchowe, smakowe,

8 Wersja rozszerzona artykułu zob. M. Johnson Embodied Meaning and Cognitive Science, w: Language beyond Postmodernism; wersja skrócona pt. Odczuwane sytuacje Gendlina jako klucz do znaczenia w tegoż Znaczenie ciała. Estetyka rozumienia ludzkiego, przeł. J. Płuciennik, Wydawnictwo UŁ, Łódź 2015. 
dotykowe), to ten nadzwyczajny, szósty zmysł, zmysł udziału, aktywuje naszą zdolność reagowania na nieuświadamiane bodźce wewnętrzne, będące komponentem naszego doświadczenia; aktywuje zdolność płynącą z poczucia partycypowania w tym, co nie jest rezultatem ani naszej decyzji, ani świadomego, intencjonalnego zaangażowania; w tym, co - chcąc nie chcąc - jest właśnie naszym udziałem w nie-tylko-ludzkiej środowiskowej wspólnocie.

Zacząłem od literatury i do niej wracam na zakończenie tych amatorskich (w obu jednak znaczeniach tego słowa) uwag dotyczących niektórych tylko wątków w etnograficzno-antropologicznych dociekaniach przedtekstowej strony poznawczego doświadczenia. Wydaje mi się bowiem uderzające (i warte refleksji) retoryczno-literackie wyrafinowanie prezentowanych tu etnograficznych tekstów. Wydaje mi się także bardzo symptomatyczne częste sięganie do tekstów literackich i to nie w charakterze ilustracji naukowych analiz, lecz w roli autentycznych narzędzi poznawczych, dających wgląd w zakamarki i zagadki ludzkiego doświadczania świata czy dostęp do nich. Niewykluczone zatem, że na tym terenie - sztuki artykulacji ludzkiego doświadczenia "na krawędzi natury" - mogą się spotkać lub bodaj przeciąć ścieżki poszukiwań artystów i pisarzy, etnografów i antropologów, a także badaczy innych humanistycznych i już nie-tylko-humanistycznych specjalizacji. 


\section{Abstract}

\section{Ryszard Nycz}

JAGIELLONIAN UNIVERSITY (CRACOW)

THE INSTITUTE OF LITERARY RESEARCH OF THE POLISH ACADEMY OF SCIENCES (WARSAW)

Discovering the Sense of Taking Part

'The sense of taking part' - this formula (from Wisława Szymborska's poem 'Conversation With A Stone', in Nothing Twice: Selected Poems, transl. by Stanisław Barańczak and Clare Cavanagh) constitutes Szymborska's conceptual frame for her reflections on the main assumptions and goals of the new trend in anthropology and ethnography, namely 'pretextual ethnography'. Nycz examines the consequences of broadening the subject of research to include the processes by which an organism interacts with its environment; he also examines the emergence of a methodology of learning through participation as well as the possibilities of outlining ethnographical knowledge produced as embodied knowledge.

\section{Keywords}

sense of taking part, pretextual ethnography, embodied knowledge, felt meaning 